\title{
Antidiabetic and Antihyperlipidemic Activities of Methanolic Leaf Extract of Stephania japonica in Alloxan Induced Diabetic Rats
}

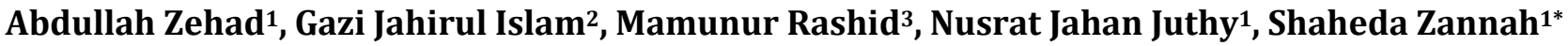 \\ ${ }^{1}$ Department of Pharmacy, Southeast University, Dhaka, Bangladesh \\ ${ }^{2}$ Department of Chemistry, University of Barisal, Barisal, Bangladesh \\ ${ }^{3}$ Department of Pharmacy, University of Rajshahi, Rajshahi, Bangladesh \\ Email: zehad510@gmail.com, ${ }^{*}$ kazi.zannah@gmail.com
}

How to cite this paper: Zehad, A., Islam, G.J., Rashid, M., Juthy, N.J. and Zannah, S. (2017) Antidiabetic and Antihyperlipidemic Activities of Methanolic Leaf Extract of Stephania japonica in Alloxan Induced Diabetic Rats. Pharmacology \& Pharmacy, 8, 109-127.

https://doi.org/10.4236/pp.2017.84008

Received: February 25, 2017

Accepted: April 17, 2017

Published: April 20, 2017

Copyright $(9) 2017$ by authors and Scientific Research Publishing Inc. This work is licensed under the Creative Commons Attribution International License (CC BY 4.0).

http://creativecommons.org/licenses/by/4.0/ (c) (i) Open Access

\begin{abstract}
This present study was aimed to investigate the antidiabetic and antihyperlipidemic activities of methanolic leaf extract (LE) of Stephania japonica alone and in combination with metformin in alloxan induced diabetic rats. Primarily acute toxicity study and oral glucose tolerance test were performed. Diabetes was confirmed after 12 days of single intraperitoneal injection of alloxan $(120 \mathrm{mg} / \mathrm{kg} \mathrm{BW})$ in albino male rats. Rats were divided into six groups'; normal control (Group I) and diabetic induced groups as (Group II, III, IV, V and VI). Group III \& IV were treated with leaf extract of $S$. japonica $(200 \mathrm{mg} / \mathrm{kg} \mathrm{BW} \mathrm{\&} 350 \mathrm{mg} / \mathrm{kg} \mathrm{BW})$. Group V (Met $850 \mathrm{mg} / 70 \mathrm{~kg} \mathrm{BW}$ ) and group VI: (combination of Met $425 \mathrm{mg} / 70 \mathrm{~kg} \mathrm{BW}$ and LE $250 \mathrm{mg} / \mathrm{kg} \mathrm{BW}$ ) for four weeks. Body weight of each rat in the different groups was recorded at 0 , $7^{\text {th }}, 14^{\text {th }}, 21^{\text {st }}$ and $28^{\text {th }}$ day of treatment. TC, TG, LDL-C and HDL-C were measured analytically after 28 days of treatment. Alloxan induction also caused left ventricular hypertrophy. LE of $S$. Japonica showed a good result in OGTT. Oral treatment of different doses of LE and combination therapy reduced elevated level of BG, TC, TG, LDL-C and increased HDL-C level significantly $(\mathrm{p}<0.001)$ but extract $(350 \mathrm{mg} / \mathrm{kg} \mathrm{BW})$ therapy was the most effective. Moreover, LE reduced LVH and improved BW of each rat. Extract from $S$. japonica (Thunb.) Miers showed antihyperlipidemic and antidiabetic effect and hence could be suggested as a potential therapeutic agent for diabetic treatment.
\end{abstract}

\section{Keywords}

Diabetes Mellitus, Methanolic Extract, Antihyperglycemic Activity, Blood Glucose, Lipid Profile 


\section{Introduction}

Diabetes mellitus (DM) is a chronic metabolic disorder that occurs when the body cannot produce sufficient insulin or cannot utilize insulin effectively. Early symptoms concern hyperglycemia and encompass excessive thirst, excessive eating, production of excessive amount of dilute urine and blurred vision. Later complications encompass an abnormal condition of the blood vessels, peripheral neuropathy, nephropathy and tendency to suffer from infection. Almost every organ system in the body can be affected by diabetes mellitus [1].

According to World Health Organization there were 171 million people with diabetes throughout the world in the year 2000 and this is often predicted to extend to 366 million by 2030 [2]. The American Diabetes Association (ADA) estimated the national expenses of diabetes in the USA for 2002 to be US132 billion, increasing to US192 billion in 2020 [3]. Recently, biguanides, thiazolidinediones, sulfonylureas, D-phenylalanine and $\alpha$-glucosidase inhibitors along with insulin are extensively used in the treatment of diabetes by a sustained reduction in hyperglycemia. However, due to enormous unwanted side effects and in addition to high cost of allopathic drugs the effectiveness of these compounds are not acceptable and there is an increasing demand for both effective as well as safer drug compounds for the treatment of diabetes Mellitus [4] [5]. To avoid side effects of insulin and oral hypoglycemic agents, patient's interest are expanding to use traditional plants with antidiabetic activity [6] [7] [8].

From ethnobotanical information it has been reported that about 800 traditional plants may carry anti-diabetic potential, among all of them Momordica charantia, Pterocarpus marsupium, Allium sativum, Azadirachta indica, Vinca rosea, and Trigonella foenum-greacum, these all are effective in lowering glucose levels in severe diabetes [9] [10]. The plant Stephania japonica have been claimed to possess various medicinal properties. A juice of the whole plant is employed in treatment of convulsions, skin diseases, cough, asthma like symptoms and kidney disorders [11] [12] [13] [14] [15]. S. japonica (Thunb.), Miers, Synonyms: S. hernandifolia Walp; Menispermum japonicum Thunb. Bengali/Vernacular Name: Akanadi, Nimuka, Maknadi (Family: Menispermaceae) is a thin, soft woody climber. Leaves are peltate, broadly triangular ovate-acuminate. Flowers are greenish-white to light yellow in color.

It is generally found in native to eastern and southern Asia and Australia. In Bangladesh, it is grown in all over the country. The whole plant is bitter in test and the leaves and roots of these plants are used in fevers, diarrhoea, dyspepsia, rheumatism and urinary disease [16] [17]. Leaves and roots are bitter and astringent; used in fever, diarrhoea, urinary diseases and dyspepsia. Different studies have shown that a crude methanolic extract exhibited good analgesic activity, vital cytotoxic activity and moderate antioxidant activity [18]. Study of Stephania japonica roots showed diuretic activity [19]. Multidrug-resistance-reversing action was shown by alkaloidal extract of vines of Stephania japonica [20]. On all phases of carrageenan-induced inflammation Stephania japonica showed vital anti-inflammatory effect [21]. Previous study have shown that it 
has anti-diarrheal effect as in a castor oil-induced diarrheal model the extract reduced a total number of stool [21]. Recent study of fresh fruits obtained a hasubanan ester-ketal alkaloid, stephabenine [22].

Methanolic extract of $S$. japonica leaves showed antinociceptive result in the treatment of assorted painful conditions [23]. To find new hypoglycemic agents from various plants and to evaluate their activity and toxicity on experimental animals and human beings, several studies have been performed [24] [25]. This research paper reports about the assessment of the hypoglycemic activity of methanolic leaf extracts of Stephania japonica (Thunb.), Miers, from the family of Menispermaceae to the standard reference metformin and with the combination with metformin.

\section{Materials and Methods}

\subsection{Chemicals}

Alloxan was purchased from Sigma chemicals, Germany. Glucose was purchased from Glaxo Smith Kline. Triglycerides, total cholesterol, HDL-cholesterol and LDL-cholesterol kits were purchased from LINEAR CHEMICALS S.L., Spain. Metformin was obtained from Chad well Heath Essex, England. All other chemicals used in the study were of analytical grade. All solutions were prepared on the same day of experiments.

\subsection{Plant Materials}

The leaves of $S$. japonica (Thunb.), Miers were collected from surrounding area of Hazrat Shahjalal International Airport, Kurmitola, Dhaka-1229, in March, 2015. The plants were identified by expert of Bangladesh National Herbarium, Mirpur, Dhaka, Bangladesh, where the voucher specimen has been deposited. Accession number DACB-41232 for $S$. japonica.

\subsection{Preparation of Extracts}

After collecting, the leaves were thoroughly washed with water and were well sun-dried for one week. The leaves were ground into coarse powder with the help of a suitable grinder. Dried leaf powder (500 g) was soaked in $2000 \mathrm{ml}$ methanol in a separate clean, round bottomed flask for about 7 days at room temperature with occasional shaking. After 7 days the solution was filtered using cotton filter and Whatman's filter paper. After completion of filtration the filtrate was concentrated using a rotate evaporator at $40^{\circ} \mathrm{C}$ until the extra solvent completely dried. A semi solid $S$. japonica (Thunb.) extract was obtained after complete elimination of alcohol under reduced pressure.

\subsection{Selection of Animal}

Six-weeks-old male and Long-Evans rats (115 - $120 \mathrm{~g})$ were purchased from animal's house of Jahangir Nagar University, Department of Pharmacy. Before initiation of the experiment, the rats were acclimatized for a period of 7 days under standard environmental conditions at $25^{\circ} \mathrm{C}$, humidity $(50 \% \pm 5 \%)$ and 12 
hrs. light \& 12 hrs. dark cycles). Before and during the experimental rats were fed with standard pellets supplied from ICDDR, B and fresh drinking water [26]. All the animal studies were carried out in accordance with the Animal Ethical Committee of Southeast University, Pharmacy Department.

\subsection{Acute Oral Toxicity Studies}

For the determination of acute toxicity studies the animals were divided into five groups $(\mathrm{n}=5)$ and fasted overnight. All groups' animals were fed with different doses of methanolic extract of $S$. japonica in increasing dose level 100, 250, 300, 400 and $500 \mathrm{mg} / \mathrm{kg}$ body weight. The animals were periodically observed for 72 hrs for the mortality and general behavior. After one week it has been observed that 2 out of 3 rats taking $500 \mathrm{mg} / \mathrm{kg}$ methanolic extract of $S$. japonica died. The method of Litchfield and Wilcoxon were followed to determine acute toxicity [27].

\subsection{Oral Glucose Tolerance Test (OGTT)}

Oral glucose tolerance test was performed in overnight $(18 \mathrm{~h})$ starved normal Long-Evans rat. The rats were randomly divided into five groups, each consisting of five rats $(n=5)$.

Group I: rats were administered $0.9 \%(w / v)$ saline

Group II: rats were administered methanolic leaf extract of $S$. japonica (200 $\mathrm{mg} / \mathrm{Kg} \mathrm{BW)}$

Group III: rats were administered methanolic leaf extract of $S$. japonica (350 $\mathrm{mg} / \mathrm{Kg} \mathrm{BW})$

Group IV: rats were administered standard drug metformin $(850 \mathrm{mg} / 70 \mathrm{Kg}$ BW)

Group V: rats were administered combination of leaf extract $(250 \mathrm{mg} / \mathrm{Kg} \mathrm{BW})+$ Metformin (425 mg/70 Kg BW)

Glucose $2 \mathrm{~g} / \mathrm{kg}$ BW was fed $30 \mathrm{~min}$ after the administration of different doses of leaf extract and combination drugs. Blood was withdrawn from the tail vein at 0, 30, 60, 90 and 120 min of glucose administration, blood glucose level were estimated by using glucometer (Tyson Bioresearch, Based Industrial Park, Chu-Nan, Taiwan).

\subsection{Grouping of Experimental Animals}

Long-Evans rats were randomly assigned into group I, II, III, IV, V and VI. Five rats in each group for the respective four weeks treatment protocol for the determination of blood glucose level and lipid profile test studies.

Group I: Normal Control rats administered saline water only

Group II: Diabetic Control rats administered saline water only (Alloxan treated group)

Group III: Diabetic tested rats administered methanolic leaf extract of $S$. japonica (200 mg/Kg BW)

Group IV: Diabetic tested rats administered methanolic leaf extract of $S$. japo- 
nica (350 mg/Kg BW)

Group V: Diabetic tested rats administered standard drug metformin (850 $\mathrm{mg} / 70 \mathrm{Kg} \mathrm{BW})$

Group VI: Diabetic tested rats administered combination of leaf extract (250 $\mathrm{mg} / \mathrm{Kg} \mathrm{BW})+$ Metformin (425 mg/70 Kg BW).

\subsection{Experimental Induction of Diabetes}

Here in this study alloxan is used as a diabetogenic agent. Except normal control rats, Group-II to group-VI animals were allowed to fast for 12 hours followed by injecting a freshly prepared solution of alloxan $(120 \mathrm{mg} / \mathrm{kg} \mathrm{BW})$ in saline water intraperitoneally after base line glucose estimation was done. The alloxan treated animals were not allowed to food overnight and drink $10 \%$ glucose solution to overcome initial drug induced hypoglycemia. Normal control grouped rats are allowed to take saline water only as vehicle. The fasting blood glucose level was estimated after 72 hrs from alloxan administration. The fasting blood glucose level was estimated by using glucometer (Tyson Bioresearch, Based Industrial Park, Chu-Nan, Taiwan) by the blood sample which was collected from the tail vein from the rats. Animals with blood glucose levels above $15.0 \mathrm{mmol} / \mathrm{L}$ were selected for the study.

\subsection{Preparation of Dosage of Active Drug \& Leaf Extract}

\subsubsection{Preparation of Leaf Extracts Solution}

Leaf extract was semisolid and very slightly soluble in water. The dosage was prepared in suspension from using methanol in such a concentration that, each $0.1 \mathrm{ml}$ of solution contains leaf extract according to the dose of $200 \mathrm{mg} / \mathrm{kg}$ body weight \& $350 \mathrm{mg} / \mathrm{kg}$ body weight [28].

\subsubsection{Preparation of Metformin Solution ( 850 mg/70 Kg BW)}

Metformin was in white crystal form and freely soluble in water. The dosage was prepared in solution form, using water in such a concentration that, each $0.1 \mathrm{ml}$ of solution contained Metformin according to the dose of $850 \mathrm{mg} / 70 \mathrm{~kg} \mathrm{BW}$, since Metformin is effective in such dose in humans.

\subsubsection{Combination of Leaf Extract ( $250 \mathrm{mg} / \mathrm{Kg} \mathrm{BW})+$ Metformin (425 $\mathrm{mg} / 70 \mathrm{Kg} \mathrm{BW}$ )}

The dosage was prepared separately \& such a way that, each $0.1 \mathrm{ml}$ of solution contained plant extract and Metformin according to the dose of $250 \mathrm{mg} / \mathrm{kg}$ body weight and $425 \mathrm{mg} / 70 \mathrm{~kg}$ body weight respectively.

\subsection{Glucose Level Determination}

In all experimental rats fasting blood glucose levels were determined initially to determine the level of diabetes and thereafter every week during the four weeks study period. Blood samples were collected from end tail vein by pricking with a sharp needle and blood glucose level was determined by using glucose monitoring system (TysonBio Evolve, Based Industrial Park, Chu-Nan, Taiwan). 


\subsection{Blood Serum Collection}

After completing four weeks treatment the rats were at first anesthetized with diethyl ether. Then after cutting the abdominal skin, thoracic artery was opened. $3-4 \mathrm{ml}$ of blood was collected directly from thoracic artery by heparinized syringe. The blood samples were centrifuged at $4000 \mathrm{rpm}$ for 20 minutes at $22^{\circ} \mathrm{C}$ (Digisystem Laboratory Instruments Inc., Taiwan) and the plasma sample were frozen up at $-4^{\circ} \mathrm{C}$ until biochemical estimations. Rats were dissected; heart were removed and cleaned of the surrounding tissues (Right atrium). The organ weights were measured immediately and the ratio of organ weights to body weight ratio $(\mathrm{g} / \mathrm{kg})$ were calculated.

\subsection{Lipid Profile Test}

Leaf extract, Metformin and the combination of (leaf extract \& Metformin) were administered daily for four weeks in the alloxan-induced diabetic rats. After completing drug treatment for 28 days serum was collected and the concentration of TC, TG, LDL and HDL Cholesterol were measured by taking absorbance by UV spectrophotometer using diagnostic kits (LINEAR CHEMICALS, Spain). The ratio of LDL to HDL cholesterol was calculated.

\subsection{Measurement of Left Ventricular Hypertrophy}

The beating heart was excised from the chest cavity and immersed briefly in phosphate buffer solution at room temperature in order to wash out blood from the chambers. Later on, the atria were separated completely from the ventricles. The right and left ventricles were then separated such that the left ventricle was composed of the left ventricular free wall plus the septum. The weight of the left ventricle was taken. Left ventricular hypertrophy was determined for each animal by calculating the ratio of left ventricular weight (including the septum) and body weight (LV/BW) (an index of cardiac hypertrophy). Then left ventricular hypertrophy is calculated by the following formula.

\subsection{Statistical Analysis}

Values were expressed as mean \pm SEM for five rats in the each group. The above estimations were analyzed statistically by applying One-way analysis of variance (ANOVA) followed by Dunnet's test for multiple comparisons. The differences were considered significant when $\mathrm{P}<0.05$.

\section{Results}

\subsection{Effect on Oral Glucose Tolerance (OGTT) of Normal Rats}

To evaluate the acute study of different doses of methanolic leaves extract of Stephania japonica $(200 \mathrm{mg} / \mathrm{kg}$ BW \& $350 \mathrm{mg} / \mathrm{kg} \mathrm{BW})$, Metformin $(850 \mathrm{mg} / 70$ $\mathrm{kg} \mathrm{BW})$, and combination of methanolic extract $(250 \mathrm{mg} / \mathrm{kg} \mathrm{BW}) \&$ Metformin (425 mg/70 kg BW), when administered $30 \mathrm{~min}$, before to glucose loading caused significant reduction $(\mathrm{P}<0.05)$ in the rise in blood glucose levels, after glucose administration (Table 1). It was observed that, the different doses of 
methanolic extract (200 and $350 \mathrm{mg} / \mathrm{kg} \mathrm{BW}$ ) produced $8.82 \%, 22.06 \%$ reduction in blood glucose level at $120 \mathrm{~min}$ when compared to the normal control. In case of Metformin and the combination of metformin and extract blood glucose level decreased at $26.47 \%$ and $20.59 \%$ as compared to the normal control groups (Figure 1).

\subsection{Effect of Methanolic Leaf Extract and Metformin on Blood Glucose Level}

In administration of different doses of methanolic extract of Stephania japonica (200 mg/kg BW \& $350 \mathrm{mg} / \mathrm{kg} \mathrm{BW}$ ), Metformin (850 mg/70 kg BW), and combination of methanolic extract $(250 \mathrm{mg} / \mathrm{kg} \mathrm{BW}) \&$ Metformin $(425 \mathrm{mg} / 70 \mathrm{~kg} \mathrm{BW})$ for four weeks, BG level is decreased significantly in ADRs (Table 2). In case of methanolic extract (350 mg/kg BW) BGL is decreased by $70.64 \%$, for Metformin $(850 \mathrm{mg} / 70 \mathrm{~kg} \mathrm{BW})$ is $67.70 \%$ and for combination of [methanolic extract $(250$

Table 1. Effect of methanolic leaf extract and metformin on oral glucose tolerance (OGTT) after 28 days treatment on normal rats.

\begin{tabular}{|c|c|c|c|c|c|c|}
\hline \multirow{2}{*}{ Group } & \multirow{2}{*}{ Dose } & \multicolumn{5}{|c|}{ Blood glucose levels (mmol/L) } \\
\hline & & $0 \mathrm{~min}$ & $30 \mathrm{~min}$ & $60 \mathrm{~min}$ & $90 \mathrm{~min}$ & $120 \mathrm{~min}$ \\
\hline Group I & Saline $0.9 \%(w / v)$ & $4.2 \pm 0.32$ & $8.9 \pm 0.68$ & $8.2 \pm 0.25$ & $7.1 \pm 0.44$ & $6.8 \pm 0.36$ \\
\hline Group II & Leaf Extract (200 mg/Kg BW) & $4.7 \pm 0.27$ & $7.5 \pm 0.5$ & $6.9 \pm 0.39$ & $6.5 \pm 0.62$ & $6.2 \pm 0.52$ \\
\hline Group III & Leaf Extract (350 mg/Kg BW) & $4.6 \pm 0.38$ & $6.3 \pm 0.45^{\star}$ & $6.1 \pm 0.59^{*}$ & $5.8 \pm 0.44$ & $5.3 \pm 0.36^{*}$ \\
\hline Group IV & metformin $(850 \mathrm{mg} / 70 \mathrm{Kg} \mathrm{BW})$ & $4.8 \pm 0.27$ & $6.2 \pm 0.26^{*}$ & $5.6 \pm 0.16^{\star}$ & $5.2 \pm 0.3^{*}$ & $5.0 \pm 0.06^{*}$ \\
\hline Group V & $\begin{array}{l}\text { Leaf Extract }(250 \mathrm{mg} / \mathrm{Kg} \mathrm{BW})+ \\
\text { Metformin }(425 \mathrm{mg} / 70 \mathrm{Kg} \mathrm{BW})\end{array}$ & $4.6 \pm 0.16$ & $6.5 \pm 0.13^{\star}$ & $5.9 \pm 0.5^{\star}$ & $5.7 \pm 0.43$ & $5.4 \pm 0.32^{*}$ \\
\hline
\end{tabular}

All values represent mean \pm SEM $(n=5)$ in each group. ${ }^{\star} \mathrm{P}<0.05$; ANOVA, followed by Dunnett's multiple comparison tests.

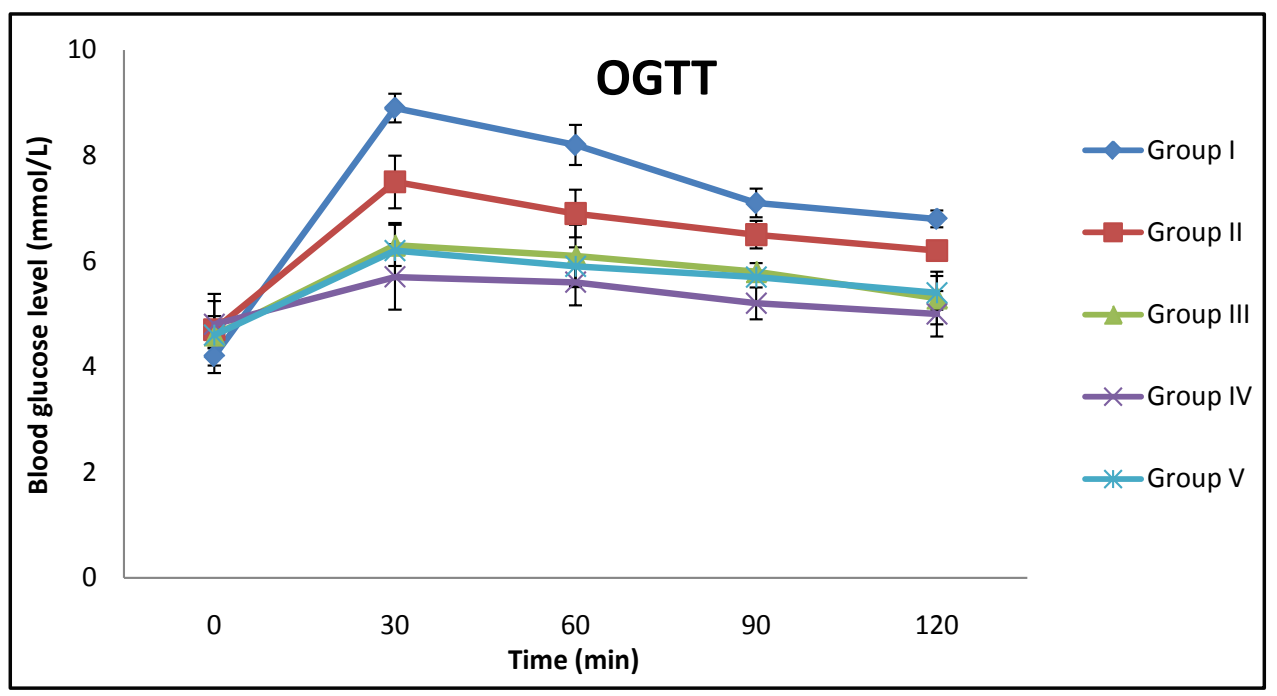

Figure 1. Effect of different doses of Stephania japonica (Thunb.) Miers on fasting plasma glucose on oral glucose tolerance test on alloxan induced diabetic rats, compared to standard drug metformin; values are mean $\pm \mathrm{SEM} ; \mathrm{n}=5 ;{ }^{\star} \mathrm{P}<0.05 ;{ }^{\star *} \mathrm{P}<0.01 ;{ }^{* \star} \mathrm{P}<0.001$; are considered as significant. 
$\mathrm{mg} / \mathrm{kg} \mathrm{BW}$ ) \& Metformin (425 $\mathrm{mg} / 70 \mathrm{~kg} \mathrm{BW})]$ is $61.18 \%$ compared to DC group. But, the methanolic extract $(200 \mathrm{mg} / \mathrm{kg} \mathrm{BW})$ did not significantly decrease blood glucose level, which is $42.32 \%$. Here the maximum reduction of blood glucose level by $62.22 \%$ was observed for methanolic extract $(350 \mathrm{mg} / \mathrm{kg}$ $\mathrm{BW}$ ), which is indicated with the arrow sign (Figure 2).

\subsection{Effect on Lipid Profile}

It had been reported that alloxan treatment not only increased blood glucose levels but also increased the levels of TC, TG and LDL cholesterol and decreased the levels of HDL cholesterol in diabetic rats. In our study it was found that the TC level (39.13\%), TG level (93.24\%), LDL-Cholesterol level (50.88\%) were increased and HDL-Cholesterol level (23.6\%) was reduced in alloxan induced diabetic rats in comparison with their respective normal rats after four weeks (Table 3) and (Figures 3-6). It has been observed that a significant reduction in TC,

Table 2. Effect of different doses of methanolic leaf extract of Stephania japonica, metformin and their combination on blood glucose level in alloxan induced diabetic rats after 28 days of treatment.

\begin{tabular}{ccccccc}
\hline Groups & $\begin{array}{c}\text { Normal } \\
\text { control (NC) }\end{array}$ & $\begin{array}{c}\text { Diabetic control } \\
(\mathrm{DC})^{\mathrm{a}}\end{array}$ & $\begin{array}{c}\text { Leaf extract 200 } \\
\mathrm{mg} / \mathrm{kg} \mathrm{BW}^{\mathrm{b}}\end{array}$ & $\begin{array}{c}\text { Leaf extract 350 } \\
\mathrm{mg} / \mathrm{kg} \mathrm{BW}\end{array}$ & $\begin{array}{c}\text { Metformin 850 } \\
\mathrm{mg} / 70 \mathrm{~kg} \mathrm{BW} \mathbf{B W}^{\mathrm{b}}\end{array}$ & $\begin{array}{c}\text { Metformin 425 mg/70 kg BW + } \\
\text { Leaf extract 250 mg/kg BW }\end{array}$ \\
\hline $\begin{array}{c}\text { BG level before four } \\
\text { weeks treatment }\end{array}$ & $5.2 \pm 0.058$ & $24 \pm 0.26$ & $26.7 \pm 0.39$ & $23.5 \pm 1.0$ & $22.6 \pm 2.0$ & $23.7 \pm 2.0$ \\
$\begin{array}{c}\text { BG level after four } \\
\text { weeks treatment }\end{array}$ & $5.7 \pm 0.2$ & $25.3 \pm 0.78^{* * *}$ & $15.4 \pm 1.5^{* * *}$ & $6.9 \pm 0.57^{* * *}$ & $7.3 \pm 0.29^{* * *}$ & $9.2 \pm 0.57^{* * *}$
\end{tabular}

All values are expressed as mean $\pm \operatorname{SEM}(n=5)$ in each group. ${ }^{*} \mathrm{P}<0.05 ;{ }^{* *} \mathrm{P}<0.01 ;{ }^{* *} \mathrm{P}<0.001$; ANOVA, followed by Dunnett's multiple comparison test. ${ }^{\mathrm{a} C}$ Compared to normal control and ${ }^{\mathrm{b}}$ Compared to diabetic control.

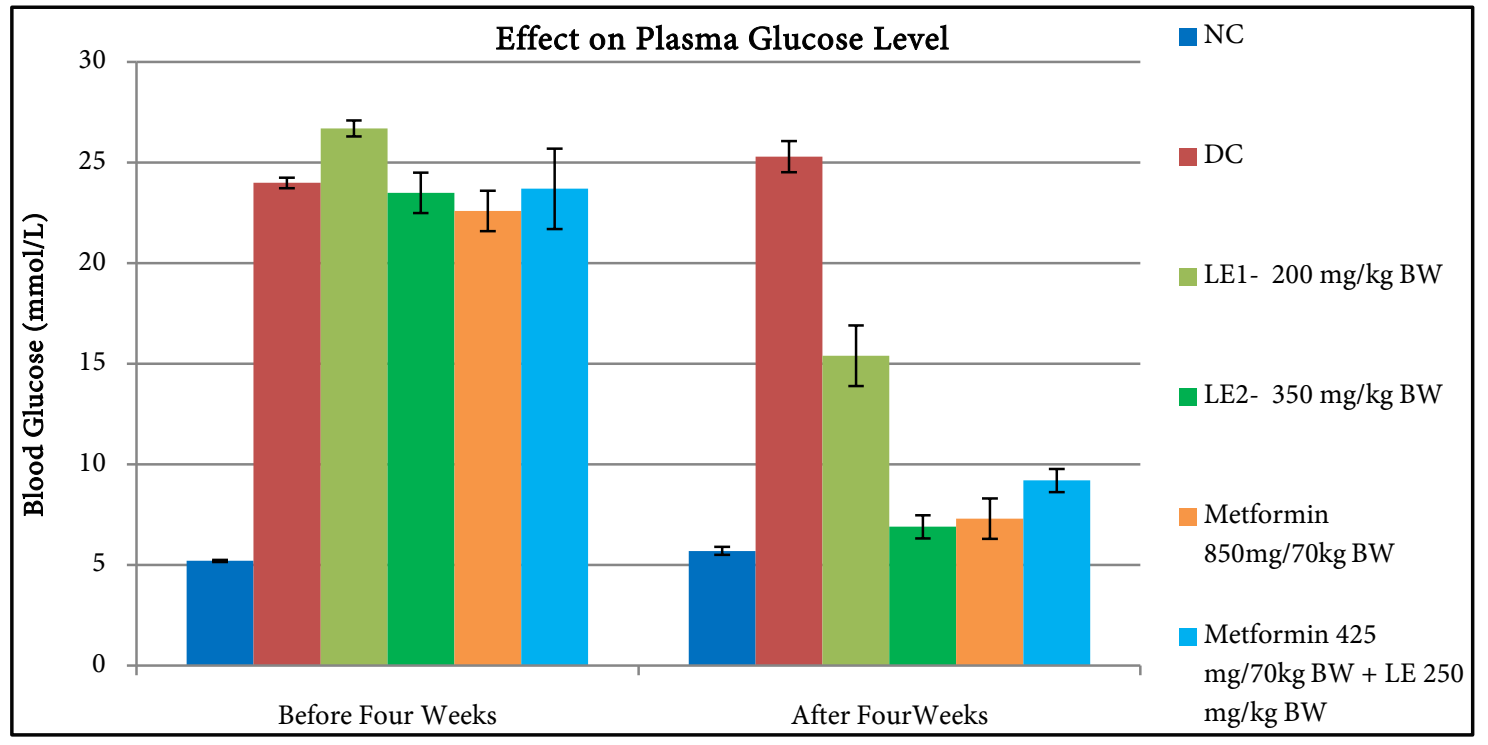

Figure 2. Effect of different doses of Stephania japonica, metformin and their combination on fasting plasma glucose on alloxan induced diabetic rat after four weeks treatment. Values are represented as mean $\pm \mathrm{SEM} ; \mathrm{n}=5$; ${ }^{\star} \mathrm{P}<0.05 ;{ }^{* *} \mathrm{P}<0.01 ;{ }^{* *} \mathrm{P}<0.001$ are considered as significant. ${ }^{\star} \mathrm{p}<0.05$ compared to diabetic control group. $+\mathrm{p}<$ 0.001 compared to normal group. Here, NC (Normal control), DC (Diabetic control), LE1 (Leaf extract 200 $\mathrm{mg} / \mathrm{kg} \mathrm{BW}$ ), LE2 (Leaf extract $350 \mathrm{mg} / \mathrm{kg} \mathrm{BW}$ ), LE (Leaf extract $250 \mathrm{mg} / \mathrm{kg} \mathrm{BW),} \mathrm{BW} \mathrm{(Body} \mathrm{weight).} \mathrm{Here,} \mathrm{de-}$ creasing sign of arrow indicates, the significant lowering of blood glucose level. 
Table 3. Effects of different doses of methanolic leaf extract of Stephania japonica, metformin and their combination on lipid profile \& LVH in alloxan induced diabetic rats after 28 days of treatment.

\begin{tabular}{cccccc}
\hline Groups & $\begin{array}{c}\text { Total } \\
\text { cholesterol }\end{array}$ & Triglyceride & $\begin{array}{c}\text { Low density } \\
\text { lipoprotein }\end{array}$ & $\begin{array}{c}\text { High density Left ventricular } \\
\text { lipoprotein }\end{array}$ & $\begin{array}{c}\text { hypertrophy } \\
\text { hol }\end{array}$ \\
\hline Normal control & $153.34 \pm 2.2$ & $123.34 \pm 2.7$ & $96.33 \pm 0.89$ & $42.33 \pm 2.2$ & 0.0032 \\
Diabetic control & $213.34 \pm 1.5^{* * *}$ & $238.34 \pm 4.4^{* * *}$ & $145.34 \pm 3.6^{* * *}$ & $32.34 \pm 2.9^{*}$ & $0.0043^{*}$ \\
Leaf extract $200 \mathrm{mg} / \mathrm{kg} \mathrm{BW}^{\mathrm{b}}$ & $167.67 \pm 1.5^{* * *}$ & $169.34 \pm 4.3^{* * *}$ & $91 \pm 1.2^{* * *}$ & $38.33 \pm 1.8^{* *}$ & $0.0027^{* * *}$ \\
Leaf extract $350 \mathrm{mg} / \mathrm{kg} \mathrm{BW}^{\mathrm{b}}$ & $154.67 \pm 0.9^{* * *}$ & $140.67 \pm 3.9^{* * *}$ & $78.67 \pm 1.3^{* * *}$ & $55.66 \pm 1.5^{* * *}$ & $0.0033^{* * *}$ \\
Metformin $850 \mathrm{mg} / 70 \mathrm{~kg} \mathrm{BW}$ & $158.34 \pm 1.8^{* * *} 149.34 \pm 2.4^{* * *}$ & $84.66 \pm 2.4^{* * *}$ & $57 \pm 3.0^{* * *}$ & $0.0029^{* * *}$ \\
Metformin $425 \mathrm{mg} / 70 \mathrm{~kg} \mathrm{BW}+\mathrm{Leaf}$ extract $250 \mathrm{mg} / \mathrm{kg} \mathrm{BW}^{\mathrm{b}}$ & $175.67 \pm 2.0^{* * *} 150.34 \pm 5.3^{* * *}$ & $99.33 \pm 2.8^{* * *}$ & $49 \pm 2.7^{* * *}$ & $0.0028^{* *}$ \\
\hline
\end{tabular}

All values are expressed as mean $\pm \operatorname{SEM}(n=5)$ in each group. ${ }^{*} \mathrm{P}<0.05 ;{ }^{* *} \mathrm{P}<0.01$; ${ }^{* *} \mathrm{P}<0.001$; ANOVA, followed by Dunnett's multiple comparison test. ${ }^{\mathrm{a}}$ Compared to normal control and ${ }^{\mathrm{b}} \mathrm{Compared}$ to diabetic control.

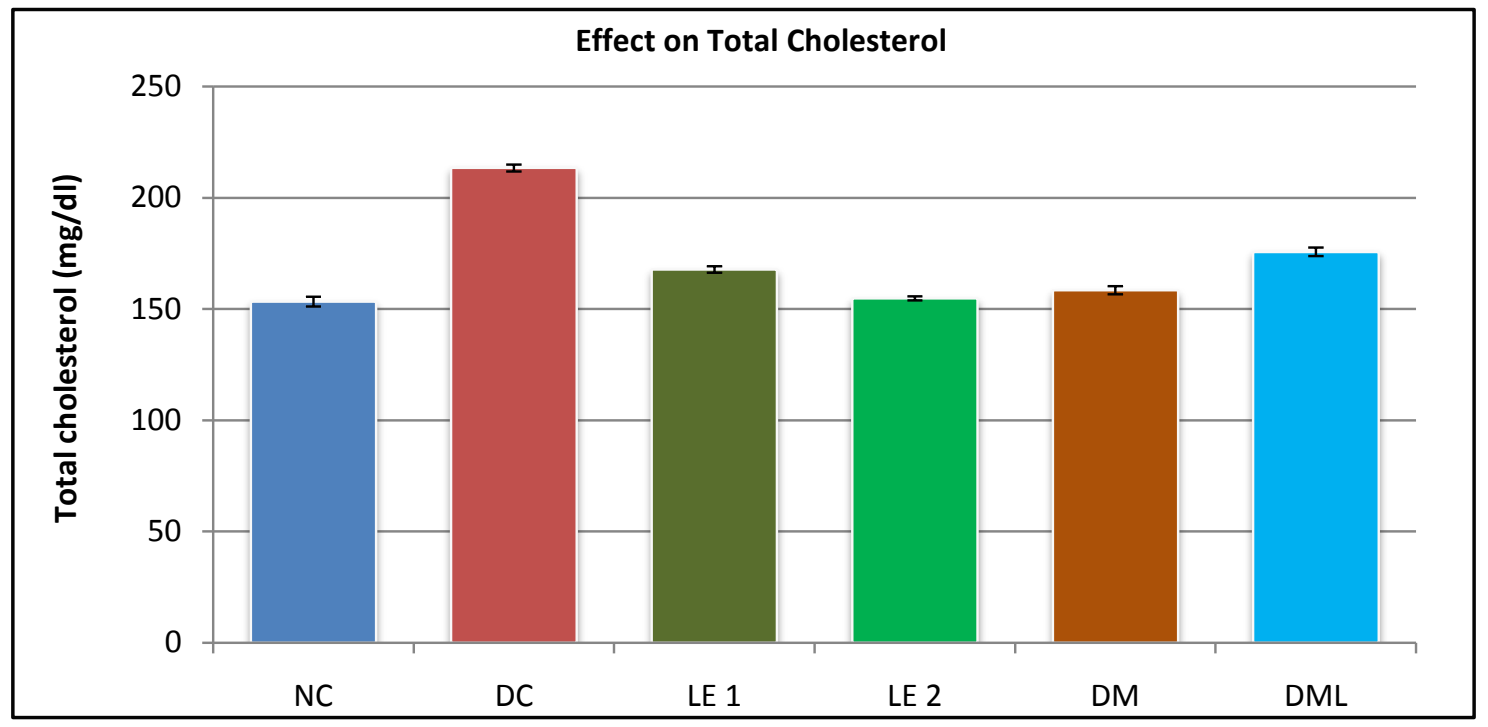

Figure 3. Effect of different doses of Stephania japonica, metformin, and their combination on total cholesterol in alloxan induced diabetic rats after four weeks treatment. Values are represented as mean $\pm \mathrm{SEM} ; \mathrm{n}=5 ;{ }^{\star} \mathrm{P}<0.05$; ${ }^{*} \mathrm{P}<0.01 ;{ }^{* *} \mathrm{P}<0.001$ are considered as significant. ${ }^{*} \mathrm{p}<0.05$ compared to diabetic control group. $+\mathrm{p}<0.001$ compared to normal group. Here, NC (Normal control), DC (Diabetic control), LE1 (Leaf extract $200 \mathrm{mg} / \mathrm{kg}$ BW), LE2 (Leaf extract $350 \mathrm{mg} / \mathrm{kg} \mathrm{BW),} \mathrm{DM} \mathrm{(Diabetic} \mathrm{+} \mathrm{Metformin} 850 \mathrm{mg} / 70 \mathrm{~kg} \mathrm{BW}$ ), DML (Diabetic + Metformin $425 \mathrm{mg} / 70 \mathrm{~kg} \mathrm{BW}+$ Leaf extract $250 \mathrm{mg} / \mathrm{kg} \mathrm{BW}$ ), BW (Body weight). Here, decreasing sign of arrow indicates, the significant lowering of total cholesterol.

TG, LDL-Cholesterol and increase in HDL-C levels in alloxan induced diabetic rats treated with either methanolic extract of Stephania japonica or metformin after four weeks treatment. The evidence represented that both the methanolic extract and combination therapy produces beneficial effects on TC, TG, LDL and HDL-Cholesterol level in ADRs after four weeks treatment. As well as standard drug metformin showed significant result in correcting dyslipidemia and normalizing blood glucose level.

\subsection{Effect on Left Ventricle}

Left ventricular hypertrophy (LVH) is the thickening of the myocardium (muscle) of the left ventricle of the heart. In our study it was observed that all treatment 


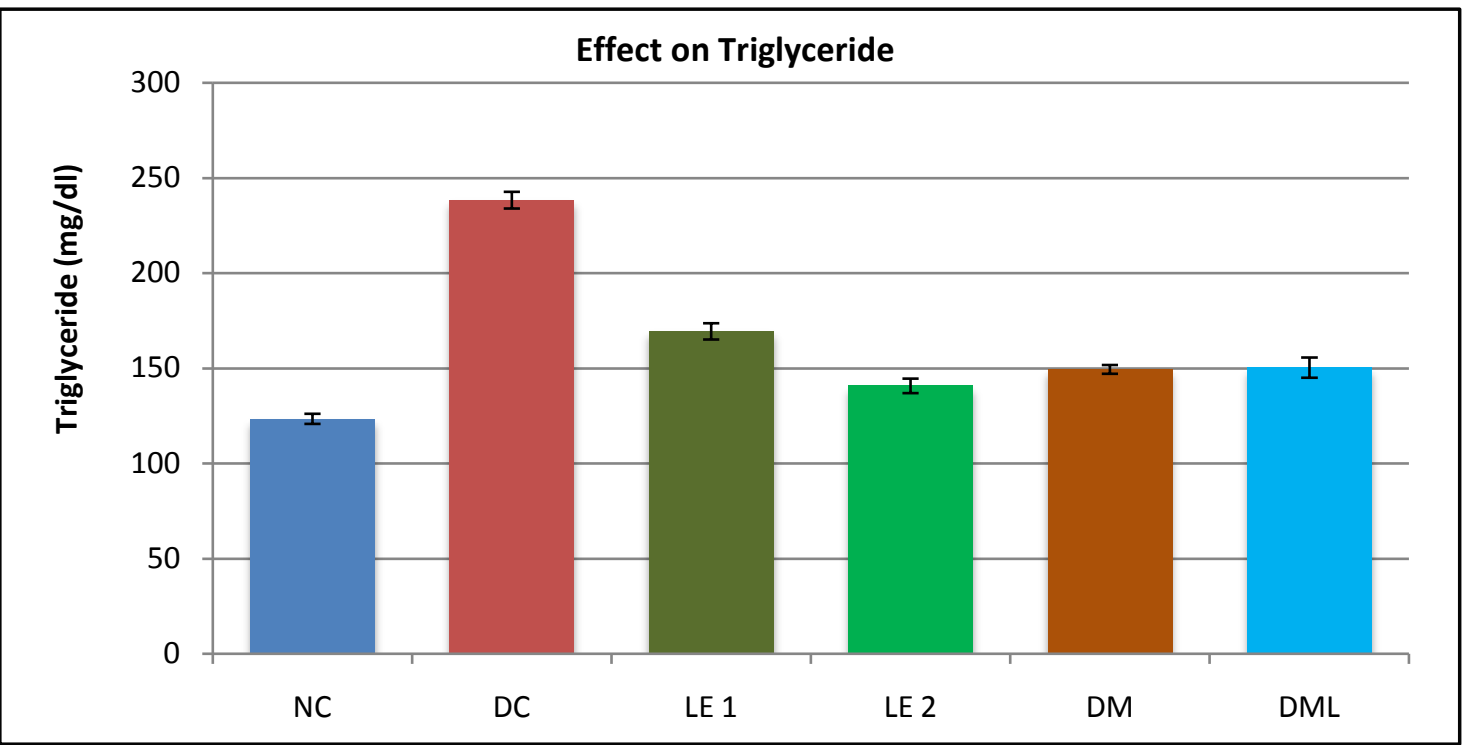

Figure 4. Effect of different doses of Stephania japonica, metformin, and their combination on triglyceride in alloxan induced diabetic rats after four weeks treatment. Values are represented as mean $\pm \mathrm{SEM} ; \mathrm{n}=5 ;{ }^{\star} \mathrm{P}<0.05$; ${ }^{* *} \mathrm{P}<0.01 ;{ }^{* *} \mathrm{P}<0.001$ are considered as significant. ${ }^{*} \mathrm{p}<0.05$ compared to diabetic control group. $+\mathrm{p}<0.001$ compared to normal group. Here, NC (Normal control), DC (Diabetic control), LE1 (Leaf extract $200 \mathrm{mg} / \mathrm{kg}$ BW), LE2 (Leaf extract $350 \mathrm{mg} / \mathrm{kg} \mathrm{BW),} \mathrm{DM} \mathrm{(Diabetic} \mathrm{+} \mathrm{Metformin} 850 \mathrm{mg} / 70 \mathrm{~kg}$ BW), DML (Diabetic + Metformin $425 \mathrm{mg} / 70 \mathrm{~kg} \mathrm{BW}+$ Leaf extract $250 \mathrm{mg} / \mathrm{kg} \mathrm{BW}$ ), BW (Body weight). Here, decreasing sign of arrow indicates, the significant lowering of triglyceride level in blood.

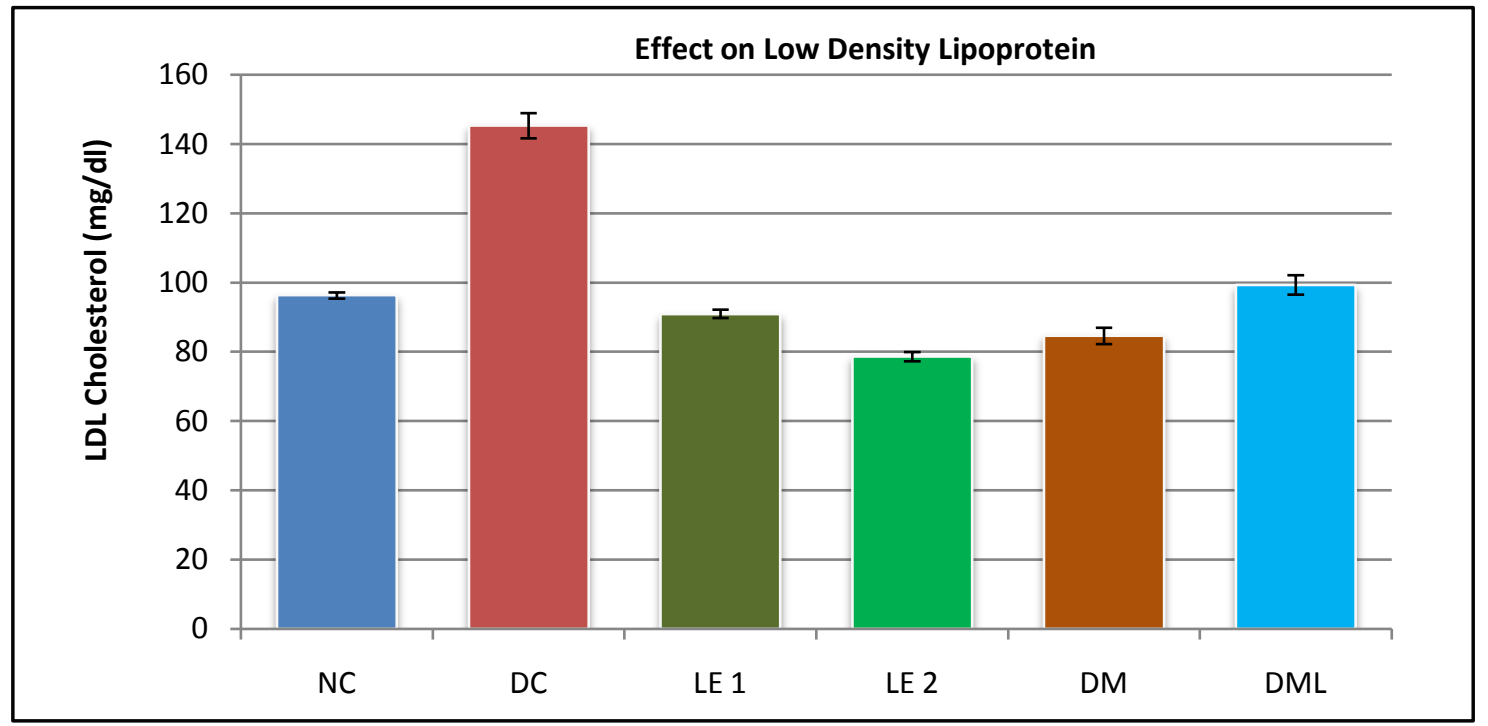

Figure 5. Effect of different doses of Stephania japonica, metformin, and their combination on LDL-cholesterol in alloxan induced diabetic rats after four weeks treatment. Values are represented as mean $\pm \mathrm{SEM} ; \mathrm{n}=5 ;{ }^{\star} \mathrm{P}<0.05$; ${ }^{*} \mathrm{P}<0.01 ;{ }^{* *} \mathrm{P}<0.001$ are considered as significant. ${ }^{*} \mathrm{p}<0.05$ compared to diabetic control group. $+\mathrm{p}<0.001$ compared to normal group. Here, NC (Normal control), DC (Diabetic control), LE1 (Leaf extract $200 \mathrm{mg} / \mathrm{kg}$ BW), LE2 (Leaf extract $350 \mathrm{mg} / \mathrm{kg} \mathrm{BW}$ ), DM (Diabetic + Metformin $850 \mathrm{mg} / 70 \mathrm{~kg} \mathrm{BW),} \mathrm{DML} \mathrm{(Diabetic} \mathrm{+} \mathrm{Met-}$ formin $425 \mathrm{mg} / 70 \mathrm{~kg} \mathrm{BW}+$ Leaf extract $250 \mathrm{mg} / \mathrm{kg} \mathrm{BW}$ ), BW (Body weight). Here, decreasing sign of arrow indicates, the significant lowering of HDL level in blood.

groups showed significant result in decreasing LVH in alloxan induced diabetic groups after four weeks treatment. The Table 3 and Figure 7 represented the 


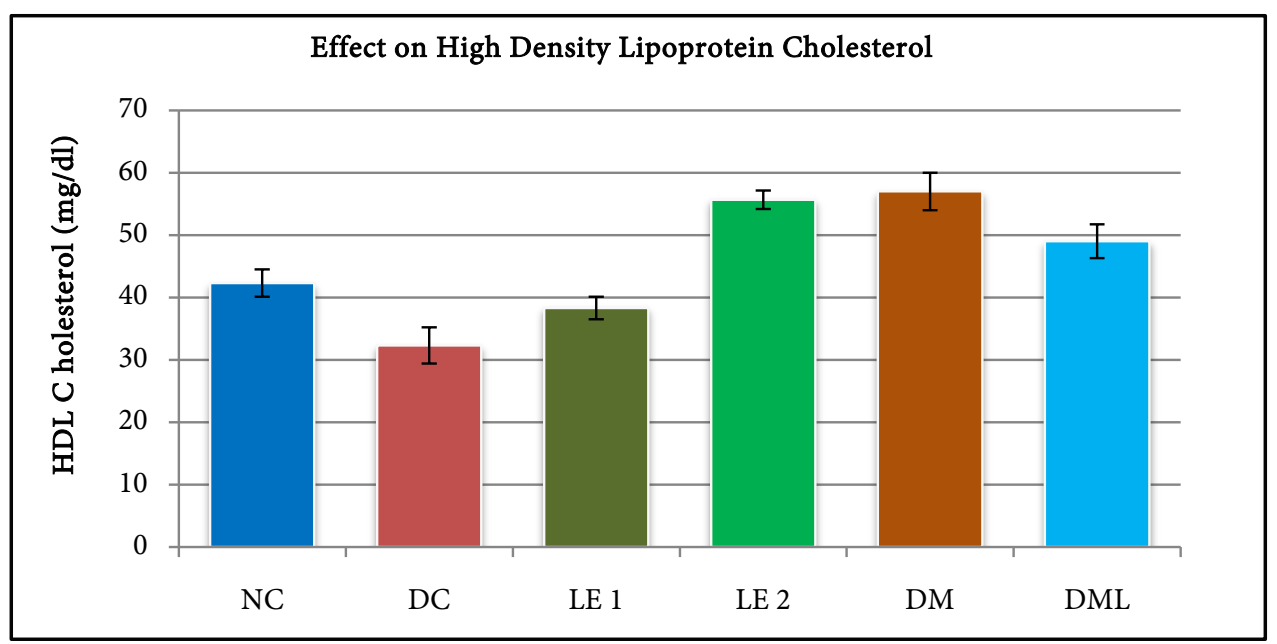

Figure 6. Effect of different doses of Stephania japonica, metformin, and their combination on HDL-cholesterol in alloxan induced diabetic rats after four weeks treatment. Values are represented as mean $\pm \mathrm{SEM} ; \mathrm{n}=5 ;{ }^{\star} \mathrm{P}<0.05 ;{ }^{* *} \mathrm{P}<0.01 ;{ }^{* *} \mathrm{P}<0.001$ are considered as significant. ${ }^{*} \mathrm{p}<0.05$ compared to diabetic control group. $+\mathrm{p}<0.001$ compared to normal group. Here, NC (Normal control), DC (Diabetic control), LE1 (Leaf extract $200 \mathrm{mg} / \mathrm{kg} \mathrm{BW),} \mathrm{LE2} \mathrm{(Leaf} \mathrm{extract}$ $350 \mathrm{mg} / \mathrm{kg} \mathrm{BW}$ ), DM (Diabetic + Metformin $850 \mathrm{mg} / 70 \mathrm{~kg} \mathrm{BW}$ ), DML (Diabetic + Metformin $425 \mathrm{mg} / 70 \mathrm{~kg} \mathrm{BW}+$ Leaf extract $250 \mathrm{mg} / \mathrm{kg} \mathrm{BW}$ ), BW (Body weight). Increasing sign of arrow indicates the significant increase of high density lipoprotein cholesterol level in blood.

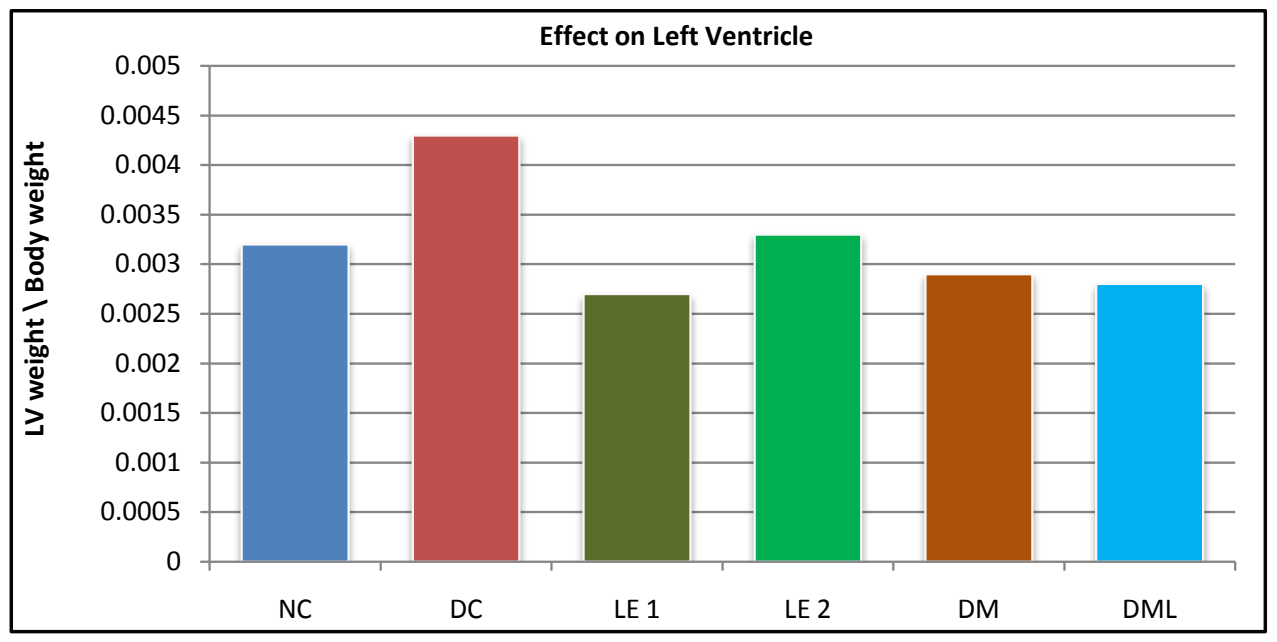

Figure 7. Effect of different doses of Stephania japonica, metformin, and their combination on left ventricle in alloxan induced diabetic rats after four weeks treatment. Values are represented as mean \pm SEM; $\mathrm{n}=5 ;{ }^{\star} \mathrm{P}<0.05 ;{ }^{\star \star} \mathrm{P}<0.01 ;{ }^{* *} \mathrm{P}<0.001$ are considered as significant. ${ }^{*} \mathrm{p}<$ 0.05 compared to diabetic control group. $+\mathrm{p}<0.001$ compared to normal group. Here, NC (Normal control), DC (Diabetic control), LE1 (Leaf extract $200 \mathrm{mg} / \mathrm{kg} \mathrm{BW),} \mathrm{LE2} \mathrm{(Leaf} \mathrm{extract}$ $350 \mathrm{mg} / \mathrm{kg} \mathrm{BW}$ ), DM (Diabetic + Metformin $850 \mathrm{mg} / 70 \mathrm{~kg} \mathrm{BW}$ ), DML (Diabetic + Metformin $425 \mathrm{mg} / 70 \mathrm{~kg} \mathrm{BW}+$ Leaf extract $250 \mathrm{mg} / \mathrm{kg} \mathrm{BW}$ ), BW (Body weight).

effect of methanolic extract of Stephania japonica, Metformin and combination of extract on left ventricle of rat's heart. It also showed the values those had significant changes in comparison with diabetic control group. It was found that the decreased level of LV for methanolic extract $(200 \mathrm{mg} / \mathrm{kg}$ BW\& $350 \mathrm{mg} / \mathrm{kg}$ BW) is $37.21 \%$ and $23.26 \%$ respectively and decreased level for metformin and 
their combination is $32.56 \%$ and $34.88 \%$ respectively. Here all the treatment groups showed significant result. But the effect of combination therapy showed greater result than extract and metformin alone.

\subsection{Effect on Body Weight}

In the present study, in comparison with normal rats alloxan induced diabetic rats showed significant $(\mathrm{P}<0.01)$ reduction in body weight. At the end of 28 days treatment, the body weight of normal rats, diabetic control, different doses of methanolic leaf extract and metformin treated rats were observed (Table $4 \&$ Figure 8). After four weeks treatment with methanolic leaf extract of $S$. japonica

Table 4. Effect of different doses of methanolic leaf extract of Stephania japonica, metformin and their combination on body weight in normal and alloxan induced diabetic rats.

\begin{tabular}{|c|c|c|c|c|c|}
\hline \multirow{3}{*}{ Groups } & \multicolumn{5}{|c|}{ Body weight in Grams } \\
\hline & \multicolumn{5}{|c|}{ Dose interval } \\
\hline & 0 day & 7 day & 14 day & 21 day & 28 day \\
\hline Normal control & $115.4 \pm 1.9$ & $126.6 \pm 1.2$ & $139.3 \pm 2.0$ & $153.7 \pm 2.7$ & $178.34 \pm 2.5$ \\
\hline Diabetic control $^{\mathrm{a}}$ & $116.7 \pm 1.3$ & $122.7 \pm 0.89$ & $115.6 \pm 1.4$ & $113 \pm 2.4$ & $109.67 \pm 2.8^{\star *}$ \\
\hline Leaf extract $200 \mathrm{mg} / \mathrm{kg} \mathrm{BW}^{\mathrm{b}}$ & $117.3 \pm 0.89$ & $124 \pm 1.6$ & $133 \pm 2.7^{\star * *}$ & $143.4 \pm 2.8^{\star * *}$ & $155 \pm 1.6^{* * *}$ \\
\hline Leaf extract $350 \mathrm{mg} / \mathrm{kg} \mathrm{BW}^{\mathrm{b}}$ & $118.4 \pm 1.5$ & $128 \pm 1.6$ & $140 \pm 1.8^{\star * *}$ & $152 \pm 1.1^{\star * *}$ & $165.34 \pm 2.2^{\star * x}$ \\
\hline Metformin $850 \mathrm{mg} / 70 \mathrm{~kg} \mathrm{BW}^{\mathrm{b}}$ & $120 . \pm .34$ & $131.4 \pm 1.9$ & $139.7 \pm 2.2^{\star * *}$ & $153 \pm 2.7^{\star * *}$ & $170.34 \pm 2.9^{\star * x}$ \\
\hline $\begin{array}{c}\text { Metformin } 425 \mathrm{mg} / 70 \mathrm{~kg} \mathrm{BW}+ \\
\text { Leaf extract } 250 \mathrm{mg} / \mathrm{kg} \mathrm{BW}^{\mathrm{b}}\end{array}$ & $118.4 \pm 0.89$ & $129 \pm 0.6$ & $138 \pm 1.1^{\star \star \star}$ & $148.3 \pm 1.9^{* * *}$ & ${ }^{*} 162.34 \pm 2.0^{\star \star \star}$ \\
\hline
\end{tabular}

All values are expressed as mean $\pm \operatorname{SEM}(n=5)$ in each group. ${ }^{\star} \mathrm{P}<0.05 ;{ }^{*} \mathrm{P}<0.01 ;{ }^{* *} \mathrm{P}<0.001$; ANOVA, followed by Dunnett's multiple comparison test. ${ }^{\mathrm{a}}$ Compared to normal control and ${ }^{\mathrm{b}}$ Compared to diabetic control.

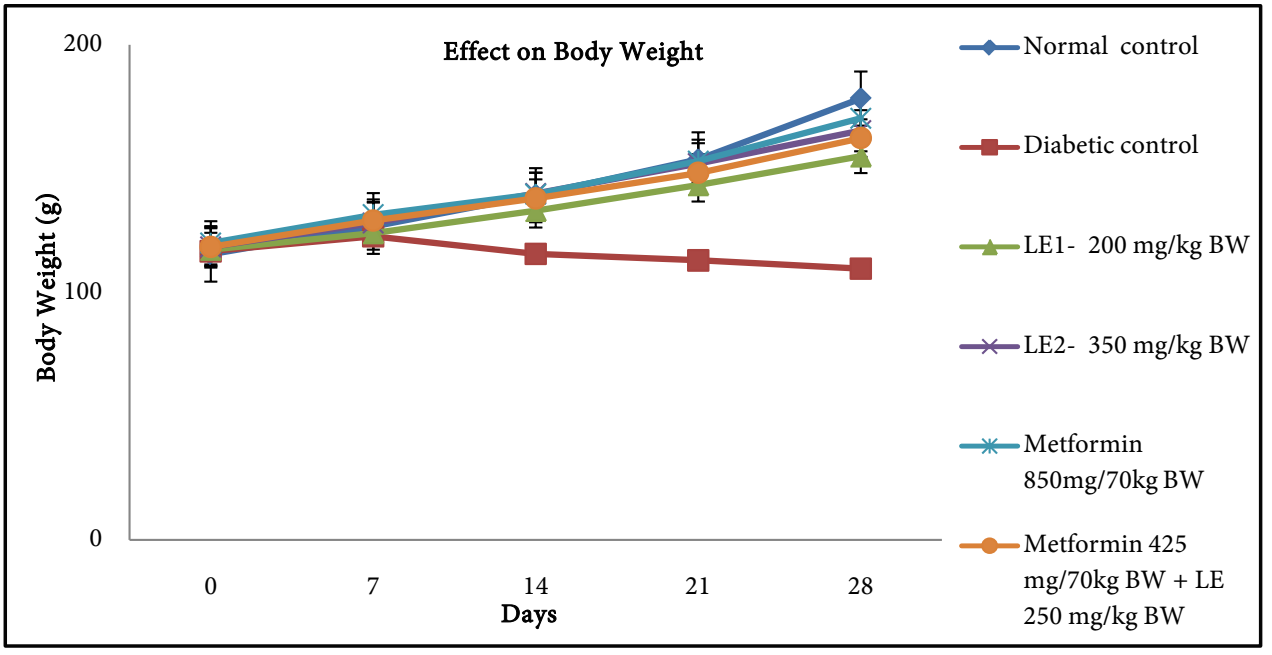

Figure 8. Effect of different doses of Stephania japonica, metformin, and their combination on body weight in alloxan induced diabetic rats after four weeks treatment. Values are represented as mean $\pm \mathrm{SEM} ; \mathrm{n}=5 ;{ }^{*} \mathrm{P}<0.05 ;{ }^{* *} \mathrm{P}<0.01 ;{ }^{* *} \mathrm{P}<0.001$ are considered as significant. ${ }^{*} \mathrm{p}<0.05$ compared to diabetic control group. $+\mathrm{p}<0.01$ compared to normal group. Here, LE1 (Leaf extract $200 \mathrm{mg} / \mathrm{kg} \mathrm{BW}$ ), LE2 (Leaf extract $350 \mathrm{mg} / \mathrm{kg} \mathrm{BW}$ ), LE (Leaf extract $250 \mathrm{mg} / \mathrm{kg} \mathrm{BW}$ ), BW (Body weight). 
and combination therapy all the treatment groups showed significant result in increasing body weight when compared with diabetic control groups. Administration of both methanolic extract of Stephania japonica $(200 \mathrm{mg} / \mathrm{kg}$ BW\& 350 $\mathrm{mg} / \mathrm{kg} \mathrm{BW})$ and metformin significantly $(\mathrm{P}<0.05)$ increased the body weight within 28 days (Table $4 \&$ Figure 8). The body weights of normal control; leaf extract treated group $200 \mathrm{mg} / \mathrm{kg} \mathrm{BW} \& 350 \mathrm{mg} / \mathrm{kg} \mathrm{BW}$; Metformin; and combination treated group increased significantly by $+68.67 \mathrm{~g} ;+45.33 \mathrm{~g} ;+55.67 \mathrm{~g} ;+60.67$ $\mathrm{g}$; and +52.67 respectively (Table $4 \&$ Figure 8 ), displays the effect of the different doses of $S$. japonica leaves extract and metformin on the body weight on the alloxan induced diabetic rats. Diabetic control group continued to decrease the weight till the end of the study.

\section{Discussion}

The pathogenesis and management of diabetes mellitus by existing antidiabetic agents without any side effects have raised great interest in recent years among the scientists [29]. Alternative or complementary medicines have been used for a long time for the treatment of diabetes. Now-a-days, with an alarming rise in the prevalence of this disease and associated treatment costs, interest in plant medicine has grown [30].

Stephania japonica (Thunb.), Miers, lie geographically in southern China [31] are well known for the medicinal uses like the tuberous root is astringent [32] in nature used in the treatment of diarrhoea and dysentery; fevers; stomach ache and dyspepsia; hepatitis; and urinary diseases [32] [33]. The root is said to be used in the cure of itches [33] [34]. This plant is used medicinally for the treatment of fevers, diarrhoea, urinary diseases and stomach-ache [35]. The crushed leaves in water form a slightly gelatinous mass which is applied to breast infections [33] [35]. Extracts from the leaves have shown mild insecticidal properties against fruit flies in Thailand [33]. Until now this plant is under extensive experiment to evaluate that either it has antidiabetic activity or not. Sultana et al.; demonstrated that, methanolic extract of Stephania japonica (Thunb.) Miers, tendril (MSJT) has potent antihyperglycemic and anti lipid peroxidative activity in alloxan induced diabetic rats [36].

Since the phytochemical constituents of leaves and tendrils are different, we have selected the leaves of Stephania japonica for evaluating antihyperglycemic and antihyperlipidemic activity in our present study. In this current study alloxan is used for the initiation of diabetes. Alloxan (2,4,5,6-pyrimidinetetrone) is an oxygenated pyrimidine by-product. Alloxan has a destructive effect on the beta cells of the pancreas. Alloxan induces diabetes by destroying the insulin-producing beta cells of the pancreas [37] [38]. In vitro studies have shown that alloxan induces cell death due to its poisonous effect on pancreatic beta cells [39]. The cytotoxic action of alloxan is mediated by reactive oxygen species; however, alloxan and the product of its reduction, dialuric acid, establish a redox cycle with the formation of superoxide radicals. These radicals endure dismutation to hydrogen peroxide. Thereafter, extremely reactive hydroxyl radicals are 
fashioned by the Fenton reaction. The action of reactive oxygen species with a coincidental large increase in cytosolic calcium concentration causes fast destruction of $\beta$ cells [40].

It was observed that, alloxan caused a definite rise in blood insulin and glucose levels with a subsequent drop of free fatty acids. In the liver of alloxantreated rats the amount of sulfhydryl groups was diminished and glutathione peroxidase activity was considerably higher which may be indicative of $\beta$ cell damage by alloxan as well as its direct effect on other tissues. It was also observed that, alloxan in vivo does not merely employ detrimental effect on pancreatic $\beta$ cells [41]. It has been reported earlier that, due to muscle destruction or degradation of structural proteins there was a loss in body weight in alloxan induced diabetic rats [42]. Oral administration of different doses of methanolic leaf extract of Stephania japonica and metformin significantly improved the body weight compared to the diabetic control rats. On the other hand, untreated diabetic control rats were gradually losing their body weight. Hence all doses of methanolic leaf extract, metformin and combination therapy showed a protective response in regulating muscle exhausting. Before starting the treatment blood glucose level increased significantly in all groups when compared with normal control rats. In administration of different doses of methanolic extract of Stephania japonica (350 mg/kg BW) \& amp; Metformin $(850 \mathrm{mg} / \mathrm{kg} \mathrm{BW})$ and combination of them (Metformin $425 \mathrm{mg} / 70 \mathrm{~kg} \mathrm{BW}+\mathrm{LE} 250 \mathrm{mg} / \mathrm{kg} \mathrm{BW}$ ) for four weeks, BGL is decreased significantly in ADRs in comparison with diabetic control rats. But the methanolic extract $(200 \mathrm{mg} / \mathrm{kg} \mathrm{BW})$ didn't significantly decrease blood glucose level. The significant antihyperglycemic activity of methanolic leaf extract of Stephania japonica may be due to the presence of hypoglycemic saponins, tannins, triterpenes, alkaloids and flavonoids etc. and it is reported that Stephania japonica leaves extract is the rich source of flavonoids and phenolic compounds [43].

Present study suggests that, methanolic extract of Stephania japonica (350 $\mathrm{mg} / \mathrm{kg} \mathrm{BW}$ ) and combination therapy have the properties to stimulate or regenerate the $\beta$-cells for the secretion of insulin. Leaves of Stephania japonica lowered hyperglycemia and it may be useful for the treatment of diabetes and associated complications. On the other hand, the mechanism of action of reference drug metformin is well documented [44] [45]. In addition, Diabetes affects both glucose and lipid metabolism [46]. The most common lipid abnormalities in diabetes are hypercholesterolemia and hypertriglyceridemia. In this study, diabetic control rats showed significant changes in lipid abnormalities [47]. Furthermore, high plasma cholesterol and triglyceride levels are major risk factors of cardiovascular disease [48]. Alloxan induced diabetic rats showed elevated plasma cholesterol, triglyceride levels and LDL-Cholesterol level but decreased level of HDL-Cholesterol level due to hyperglycemia and insulin resistance [49]. In this study, alloxan induced diabetic rats also showed significant changes in lipid abnormalities [47]. After oral administration of particular doses of methanolic leaf extract of Stephania japonica caused a momentous reduction of serum lipid levels in diabetic rats, viz. total cholesterol, triglyceride, LDL-Cholesterol level and 
improved the level of HDL-Cholesterol level after four weeks treatment. Metformin and combination therapy as well as showed significant result in correcting abnormal lipid profiles. Methanolic leaf extract of Stephania japonica may lead to conversion of the pancreatic $\beta$-cells and the resultant loss in BGL may lead to blockage of lipid peroxidation.

Plant having flavonoids, terpenoids, alkaloids, and glycosides claimed to possess antioxidant and antidiabetic activity. Flavonoids present in the plant reproduce the damaged beta cells of pancreas, and the saponin and polyphenolic compounds being within the plants suppress glucose transport by suppressing sodium glucose co-transporter-1 (S-GLUT-1) in intestine [50] [51]. Antihyperglycemic and antidyslipidemic effect of methanolic extract of the leaves of Stephania japonica might be due to the presence of flavonoids, phenolic compounds, tannins and saponin etc. Metformin corrected dyslipidemia mainly by correcting abnormal glucose metabolism [52]. As a result of decreased hepatic synthesis of VLDL it also causes moderate reduction in the triglyceride levels [53]. In our present study a similar observation has been reported. Earlier studies showed that long-term induction of diabetes without any taking of hypolipidemic agent produced cardio vascular disease [54]. Treatment with different doses of extract and combination therapy (metformin and extract) noticeably ( $\mathrm{p}$ \& lt; 0.001) reduced LV hypertrophy in AIDRs after four weeks treatment. The $\mathrm{LV} / \mathrm{BW}$ ratio was significantly lower in extract treated rats than in untreated diabetic control rats.

\section{Conclusion}

According to our data it can be terminated that Stephania japonica have significant glucose lowering activity as well as lipid lowering activity in alloxan induced diabetic rats when compared with metformin. In addition, this medicinal plant might be considered to be effective, complementary and alternative treatment for diabetes with cardiovascular disease due to improvement in left ventricular hypertrophy. Moreover, methanolic extract of S. japonica in combination with oral hypoglycemic agents may be a valuable novel therapy for the treatment of diabetes and could prevent the early onset of diabetic complications. Finally, further analysis is required to identify the exact compounds that are responsible for its antidiabetic activity and to determine their mechanism of action.

\section{Acknowledgements}

All authors are thankful to Jahangir Nagar University, Bangladesh for their support by providing us experimental rats. Special thanks to Bangladesh National Herbarium for identifying our experimental plants and also thankful to Department of Pharmacy, Southeast University for providing all the support \& equipment to continue this research work.

\section{Conflict of Interest}

All authors are in agreement with the received funding of all experimental mate- 
rials. In addition, there is no possible conflict of interests about the content, submission and publication of the manuscript.

\section{References}

[1] Kujur, R.S., Singh, V., Ram, M., Yadava, H.N., Singh, K.K., Kumari, S., et al. (2010) Antidiabetic Activity and Phytochemical Screening of Crude Extract of Stevia Rebaudianain Alloxan-Induced Diabetic Rats. Pharmacognosy research, 2, 258-263. https://doi.org/10.4103/0974-8490.69128

[2] Wild, S., Roglic, G., Green, A., Sicree, R. and King, H. (2004) Global Prevalence of Diabetes: Estimates for the year 2000 and projections for 2030. Diabetes Care, 27, 1047-1053. https://doi.org/10.2337/diacare.27.5.1047

[3] American Diabetes Association (2003) Economic Costs of Diabetes in the US in 2002. Diabetes Care, 26, 917-932. https://doi.org/10.2337/diacare.26.3.917

[4] U.K Prospective Diabetes Study Group (1995) Overview of Six Years Therapy of Type 2 Diabetes: A Progressive Disease. Diabetes, 44, 1249-1258.

[5] Moller, D.E. (2001) New Drug Targets for Type 2 Diabetes and the Metabolic Syndrome. Nature, 414, 821-827. https://doi.org/10.1038/414821a

[6] Holman, R.R. and Turner, R.C. (1991) Oral Agents and Insulin in the Treatment of NIDDM. In: Pickup, J. and Williams, G., Eds., Text Book of Diabetes, Blackwell, Oxford, 467-469.

[7] Kameswara Rao, B., Kesavulu, M.M. and Apparao, Ch. (2001) Antihyperglycemic Activity of Momordica Cymbalaria in Alloxan Diabetic Rats. Journal of Ethnopharmacology, 78, 67-71.

[8] Kameswrarao, B., Giri, R., Kesavalu, M.M. and Apparao, Ch. (1997) "Herbal Medine" in the Management by Indigenous Resources. In: Bajaj, J.S., Ed., Diabetes Mellitus in Developing Countries, Interprint, New Delhi, 375-377.

[9] Ponnusamy, S., Ravindran, R., Zinjarde, S., Bhargava, S. and Kumar, A.R. (2011) Evaluation of Traditional Indian Antidiabetic Medicinal Plants for Human Pancreatic Amylase Inhibitory Effect In Vitro. Evidence-Based Complementary and Alternative Medicine, Article ID 515647, 2011, 10.

[10] Jung, M., Park, M., Lee, H.C., Kang, Y.H., Kang, E.S. and Kim, S.K. (2006) Antidiabetic Agents from Medicinal Plants. Current Medicinal Chemistry, 13, 1203-1218. https://doi.org/10.2174/092986706776360860

[11] Cowan, M.M. (1999) Plant Products as Antimicrobial Agents. Clinical Microbiology Reviews, 12, 564-582.

[12] Singh, H., Kapoor, V.K., Phillipson, J.D. and Bisset, N.G. (1975) Diaboline from Strychnos potatorum. Phytochemistry, 14, 587-588.

[13] Singh, H., Kapoor, V.K., Piozzi, F., Passannanti, S. and Paternostro, M. (1978) Isomotiol, a New Triterpene from Strychnos Potatorum. Phytochemistry, 17, 154-155.

[14] Massiot, G., Thepenier, P., Jacquier, M.-J., Men-Oliver, L.L. and Delaude, C. (1992) Alkaloids from Roots of Strychnos potatorum. Phytochemistry, 31, 2873-2876.

[15] Adinolfi, M., Corsaro, M.M., Langetta, R., Pasilli, M., Folkard, G., Grant, W., et al. (1994) Composition of the Coagulant Polysaccharide Fraction from Strychnos potatorum Seeds. Carbohydrate Research, 263, 103-110.

[16] Ghani, A. (2003) Medicinal Plants of Bangladesh. 2nd Revised Edition, The Asiatic Society of Bangladesh, Dhaka, Bangladesh.

[17] Hullatti, K.K., Sharada, M.S. and Kuppasth, I.J. (2011) Studies on Diuretic Activity of Three Plants from Menispermaceae Family. Pelagia Research Library Der Phar- 
macia Sinica, 2, 129-134.

[18] Rahman, M.H., Badrul Alam, M., et al. (2011) Antioxidant, Analgesic and Toxic Potentiality of Stephania japonica (Thunb.) Miers. Leaf. International Journal of Pharmacology, 7, 257-262.

[19] Hullatti, K.K., Sharada, M.S. and Kuppasth, I.J. (2011) Studies on Diuretic Activity of Three Plants from Menispermaceae Family. Der Pharmacia Sinica, 2, 129-134.

[20] Hall, A.M. and Chang, C.-J. (1997) Multidrug-Resistance Modulators from Stephania japonica. Journal of Natural Products, 60, 1193-1195. https://doi.org/10.1021/np9702042

[21] Ahmed, N.U., Akter, R., Satter, M.A., Khan, M.S., Islam, F. and Abdullah, A.M. (2011) Anti-Inflammatory, Antioxidant and Anti-Diarrheal Effects of Ethanol Extract of Stephania japonica. Bangladesh Journal of Scientific and Industrial Research, 46, 437-442.

[22] Kondo, S., Matsui, M. and Watanabe, Y. (1983) Alkaloids from the Fruits of Stephania japonica Miers. I. Structure of Stephabenine: A New Hasubanan Ester-Ketal Alkaloid. Chemical \& Pharmaceutical Bulletin, 31, 2574-2577.

[23] Moniruzzaman, Md., Sarwar Hossain, Md. and Bhattacharjee, P.S. (2016) Evaluation of Antinociceptive Activity of Methanolic Extract of Leaves of Stephania japonica Linn. Journal of Ethnopharmacology, 186, 205-208.

[24] Azza, O.F., Afaf, I.A. and Mohamed, G.M. (2009) Toxicopathological Effects of Guiera senegalensis Extracts in Wistar Albino Rats. Journal of Medicinal Plants Research, 3, 699-702.

[25] Cristova, F.L., Marisa, F.A., Rita, A., Manuel, F.F. and Cristina, P.W. (2006) Metformin-Like Effect of Salvia officinalis (Common Sage): Is It Useful in Diabetes Prevention? British Journal of Nutrition, 96, 326-333. https://doi.org/10.1079/BJN20061832

[26] Khan, M.R.I., Islam, M.A., Hossain, M.S., Asadujjaman, M., Wahed, M.I.I., Rahman, B.M., et al. (2010) Antidiabetic Effects of the Different Fractions of Ethanolic Extracts of Ocimum sanctum in Normal and Alloxan Induced Diabetic Rats. Journal of Scientific Research, 2, 158-168.

[27] Litchfield, J.T. and Wilcoxon, F.A. (1949) Simplified Method of Evaluating Dose Effect Experiments. Journal of Pharmacology and Experimental Therapeutics, 96, 99-133.

[28] Gosh, S. and Suryawanshi, S.A. (2001) Effect of Vinca rosea Extracts in the Treatment of Alloxan Diabetes in Male Albino Rats. Indian Journal of Experimental Biology, 39, 748-759.

[29] Bailey, C.J. (1999) New Pharmacological Approaches to Glycemic Control. Diabetes Review, 7, 94-113.

[30] Islam, M.A., Akhtar, M.A., Khan, M.R.I., Hossain, M.S., Alam, M.K., Wahed, M.I.I., et al. (2009) Antidiabetic and Hypolipidemic Effects of Different Fractions of Catharanthus roseus (Linn.) on Normal and Streptozotocin-Induced Diabetic Rats. Journal of Scientific Research, 1, 334-344.

[31] (1994) Flora of China. Publication Author Website Publisher Missouri Botanical Garden Press; St. Louis. http://flora.huh.harvard.edu/china/

[32] Chopra, R.N., Nayar, S.L. and Chopra, I.C. (1986) Glossary of Indian Medicinal Plants (Including the Supplement). Publisher Council of Scientific and Industrial Research, New Delhi.

[33] Plant Resources of Southeast Asia. Publication Author Website. http://proseanet.org/ 
[34] Brown, W.H. (1920) Minor Products of Philippine Forests. Bureau of Forestry, Manilla.

[35] Handique, P.J. and Sharma, D. (2010) Micropropagation of Stephania Japonica, a Rare Medicinal Plant of North-East India. Journal of Hill Agriculture, 1, 102-106.

[36] Sultana, M.C., Badrul Alam, M., Asadujjaman, M. and Ahsan, M. (2012) Antihyperglycemic and Antihyperlipidemic Effects of Stephania japonica (thunb.) Miers. Tenril in Alloxan Induced Diabetic Mice. International Journal of Pharmaceutical Sciences and Research, 3, 2726-2732

[37] Lenzen S and Panten, U. (1988) Alloxan: History and Mechanism of Action. Diabetologia, 31, 337-342. https://doi.org/10.1007/BF02341500

[38] Oberley, L.W. (1988) Free Radicals and Diabetes. Free Radical Biology and Medicine, 5, 113-124.

[39] Jorns, A., Munday, R., Tiedge, M. and Lenzen, S. (1997) Comparative Toxicity of Alloxan, N-Alkyl Alloxan and Ninhydrin to Isolated Pancreatic Islets in Vitro. Journal of Endocrinology, 155, 283-293.

[40] Szkudelski, T. (2001) The Mechanism of Alloxan and Streptozotocin Action in B Cells of the Rat Pancreas. Physiological Research, 50, 536-546.

[41] Szkudelski ,T., Kandulska, K. and Okulicz, M. (1998) Alloxan in Vivo Does Not Only Exert Deleterious Effects on Pancreatic B Cells. Physiological Research, 47, 343-346.

[42] Salahuddin, M. and Jalalpure, S.S. (2010) Antidiabetic Activity of Aqueous Fruit Extract of Cucumis trigonus Roxb. in Streptozotocin-Induced Diabetic Rats. Journal of Ethnopharmacology, 127, 565-567.

[43] Senthamarai, R., Ismail, A.M., VijayaKiurbha, T.S. and Balasubramanian, P. (2012) Pharmacognostical and Phytochemical Studies on Leaves of Stephania japonica Linn. Journal of Chemical and Pharmaceutical Research, 4, 1457-1464.

[44] Krentz, A.J. and Bailey, C.J. (2005) Oral Antidiabetic Agents: Current Role in Type 2 Diabetes Mellitus. Drugs, 65, 385-411. https://doi.org/10.2165/00003495-200565030-00005

[45] Wiernsperger, N.F. and Bailey, C.J. (1999) The Antihyperglycaemic Effect of Metformin: Therapeutic and Cellular Mechanisms. Drugs, 58, 31-39. https://doi.org/10.2165/00003495-199958001-00009

[46] Sperling, M.A. and Saunders, P.A. (2000) Diabetes Mellitus. In: Behrman, R.E., Kliegman, R.M. and Jenson, H.B., Eds., Nelson Text Book of Pediatrics, 1767-1791.

[47] Ohno, T., Horio, F., Tanaka, S., et al. (2000) Fatty Liver and Hyperlipidemia in IDDM (Insulin-Dependent Diabetes Mellitus) of Streptozotocin-Treated Shrews. Life Sciences, 66, 125-131.

[48] Garg, A. (1994) Management of Dyslipidemia in IDDM Patients. Diabetic Care, 17, 224-234. https://doi.org/10.2337/diacare.17.3.224

[49] Goldberg, I.J. (2001) Diabetic Dyslipidemia: Causes and Consequences. The Journal of Clinical Endocrinology \& Metabolism, 86, 965-971. https://doi.org/10.1210/jcem.86.3.7304

[50] Hakkim, F.L., Girija, S., Kumar, R.S. and Jalaluddeen, M.D. (2007) Effect of Aqueous and Ethanol Extracts of Cassia auriculata L. Flowers on Diabetes Using Alloxan Induced Diabetic Rats. International Journal of Diabetes and Metabolism, 15, 100-106.

[51] Tiwari, A.K. and Rao, J.M. (2002) Diabetes Mellitus and Multiple Therapeutic Approaches of Phytochemicals: Present Status and Future Prospects. Current Science, 83, 30-38. 
[52] DeFronzo, R.A. and Goodman, A.M. (1995) Efficacy of Metformin in Patient with Non-Insulin-Dependent Diabetes Mellitus. The New England Journal of Medicine, 333, 541-549. https://doi.org/10.1056/NEJM199508313330902

[53] Chehade, J.M. and Mooradian, A.D. (2000) A Rational Approach to Drug Therapy of Type 2 Diabetes Mellitus. Drugs, 60, 95-113. https://doi.org/10.2165/00003495-200060010-00006

[54] Tsutsui, H., Kinugawa, S., Matsushima, S. and Yokota, T. (2011) Oxidative Stress in Cardiac and Skeletal Muscle Dysfunction Associated with Diabetes Mellitus. Journal of Clinical Biochemistry and Nutrition, 48, 68-71.

https://doi.org/10.3164/jcbn.11-012FR

\section{Scientific Research Publishing}

Submit or recommend next manuscript to SCIRP and we will provide best service for you:

Accepting pre-submission inquiries through Email, Facebook, LinkedIn, Twitter, etc. A wide selection of journals (inclusive of 9 subjects, more than 200 journals)

Providing 24-hour high-quality service

User-friendly online submission system

Fair and swift peer-review system

Efficient typesetting and proofreading procedure

Display of the result of downloads and visits, as well as the number of cited articles Maximum dissemination of your research work

Submit your manuscript at: http://papersubmission.scirp.org/

Or contact pp@scirp.org 